Brit. J. industr. Med., 1962, 18, 47.

\title{
A SWISS MANUFACTURER SEES THE INDUSTRIAL REVOLUTION IN ENGLAND*
}

\author{
BY \\ HEINRICH BUESS \\ From the Medical Department, CIBA Ltd., Basle, Switzerland \\ (RECEIVED FOR PUbliCATION AUgUST 10, 1961)
}

\begin{abstract}
I have recently come across the diaries of Johann Conrad Fischer. These diaries span six decades and cover the years of social, economic, and technological upheaval which marked the industrial revolution in England. The reader is given a picture of these years through the eyes of a Swiss manufacturer with a good perception of history, and his notes are of some value to historians.
\end{abstract}

In the course of studies of scientific history, I have recently met with the unique diaries of a great citizen of Schaffhausen. Johann Conrad Fischer (1773-1854) was the founder of the Georg Fischer steel works at Schaffhausen. In the diaries he declares himself to be a "coppersmith and bellfounder, and expert in both crafts together, such as the manufacture of cast steel and files". The diaries have been re-edited for the 150th anniversary of the steelworks by Schaffhausen's historian Carl Schib. $\dagger$

Fischer's diaries cover his visits to England and are of considerable attraction for those interested in social history. They lead into the period of the industrial revolution. What is particularly valuable about his travel books is the fact that they span a period of nearly six decades (1794-1851). The reader is therefore given a cross-section of the important events of the time in the social evolution of a country which is generally reputed to have been in the forefront in the development of modern industry.

\section{The Author}

Travelling seems to have been popular in the Fischer family. For Johann Conrad's father the British Isles were one of the longed-for goals. Our author kept diaries for the years 1794, 1814, 1825, 1825 to $1827,1845,1846$, and 1851 , all of which were published in his lifetime. Thanks to two considerable inventions, the first production of crucible steel on the Continent of Europe and the production of

*From a paper read to the Thackrah Club at its meeting in Basle, May 15, 1961.

†Johann Conrad Fischer. Tagebücher. Neu herausgegeben von der Georg Fischer Aktiengesellschaft, Schaffhausen. Bearbeitet von Karl Schib. Schaffhausen, 1951. shaped castings, his name is written with golden letters in the annals of technology.

Why did Fischer publish his diaries of which the first is devoted to Basle's dyer "Hans Jakob Wybert"? First, he wanted to delineate a pattern of industrial power for his colleagues and countrymen, which he thought would serve as an encouragement at Schaffhausen. Then admiration, enthusiasm, and the desire to thank his hosts made him write and finally publish the diaries of his travels in England.

His observations provided many ideas for his own manual and industrial work. Fischer was of impressive appearance. He had a good command of the English language. Doors opened for him, even those of jealously guarded places of production. He was a thoughtful man, with a good perception of history and his notes are of much value to the historian. In studying his diaries in the light of Charles Morazés new work on the history of the 19th century (Morazé, 1959), one has the impression that they are almost illustrations of the chapters on England. Let us follow Fischer's and Morazé's invitation to accompany them on their journey to England.

\section{Coach and Railway}

How cosy sound the scenes in the old and often comfortable mailcoaches! Full of admiration the traveller tells of England's post-horses, their beauty and speed. From "Dower" to London is 72 miles; they seem to the Swiss extremely short. He is full of praise about the country's appearance of prosperity and wealth. The extensive, carefully cultivated hopfields and the beautiful "sheep-walks", where the animals were very well cared for, stood out con- 
spicuously in comparison with France. Fischer does not grow tired of confirming this impression of the year 1814 and later.

The less enjoyable habits of his companions in the coaches are drastically shown to us. Travelling on outside seats must often have been rather harassing.

And then, 30 years later, he had his first experience of the railway. In England it had been used since 1829 for passenger traffic. Mountains had to make room for this monster; the "utmost darkness" of tunnels impressed him and is illustrated by a quotation from Friedrich Schiller.

Then one can read further (Report of 1845, p. 491): "With the speed one travels at now-a-days, and particularly on railways, one cannot even watch the country things, so fast they fly before one's eyes, there is no time to describe them". Fischer, the travelied man, on a railway journey from Euston to Leeds, which measures 205 miles, noted: "In an hour one covers the distance of twelve miles, .... a speed I did not meet anywhere else". The keeping of punctual times is emphasized. On the journey from Sheffield to London, that endured from half past eight in the morning until seven o'clock in the evening the train stopped very often, and Fischer had the companionship of only one single traveller for the whole journey. Curiously, there is little mention of railway accidents, which by 1845 had become a serious problem (Ritchie, 1846).

He regarded the upholstery in the first-class carriages as the effect of an "inhuman spirit of speculation for gain". In this diary an unusually critical tone aims at the provision of the same comfort for all passengers as had been done in Austria, Baden, and Bavaria. The first provision of ventilation (1845) was agreeable.

Already in 1840 the railway network was extensive, and "the winged messenger, the electro-magnetic telegraph", had appeared.

All these daring innovations, above all the organization of the railways, incited Fischer to considerations and discourses about Swiss policies for railway traffic. The construction of a line from Basle via Waldshut to Schaffhausen weighed on his mind for understandable reasons. After several failures of English railways he thought carefully over the profit of the projected lines. On this particular point the English were in no way exemplary. It seemed that the audacious spirit of enterprise lacked advisable criticism.

\section{Culture and Science}

Sketches of a poetical taste and epical design are presented by Fischer where he reports the World
Exhibition of 1851 . He was then 78 but risked the somewhat formidable journey for the purpose of seeing the great Exhibition.

Fischer was perfectly in earnest. After crossing the Channel on June 7, 1825, he reports that the coast of Albion spreads out "like an immense blotting-case". Here probably the great enthusiasm of his life came strongly upon him: "And now-so I said to myself-thus I see you again, you strange island, you sovereign in five continents! Eleven years ago I left the smoking workshops of this country, the constantly increasing activity of its inhabitants . ..., London's boundless crowd, and the roadstead covered with ships." At sight of "the villages hidden between trees and dark-green hedges and the factories surrounded by walls, where the high smoking chimneys reveal the work of the immeasurable lever of English industry", the prayer broke from his lips that he might have the force needed to construct even a few examples of so many remarkable objects.

Fischer is astounded by the contrast between the dockyards, bridges, and streets he saw in 1814 with those of 1851 , to say nothing of the 66,000 new houses built in the years 1823 and 1824. The "active neighbour of the old Thule" is the sovereign of the world, encompassing "the terrestrial globe as with a clasp". Business, "mind and sense for industry", as he said in 1827, helped Great Britain to her position of superiority which he thought had reached the culminating point. He sees one of the secrets of this success in the enterprises led by groups and societies, contrasting this with Switzerland, where "people cannot realize the force of common work" (p. 263, diary of 1825).

The 1851 Exhibition reflected the wealth of "small Albion". In remembrance of his visit he wrote: "Whoever observes the new results in physics and chemistry and considers the differences between 1791 and 1851, will be astonished at the progress made in this short space of time". His last diary concludes with a brave plea for a realistic commercial and industrial development policy in Switzerland, based on the English experience.

Fischer found cultural value in the prints and cutglass he saw in country houses. Wedgwood gave him a remarkable warning in 1814: "I cannot advise you to buy porcelain here from me, because you are to travel back through France, and you will get it much better in Paris: I shall probably give up the manufacture of porcelain completely."

He gives a full description of the Exhibition in Hyde Park and was most impressed by the waterplays with the beautiful cascades falling from tall chandeliers. How proud the English people were of this Exhibition is shown by the fact that Queen 
Victoria and many companies deemed it an honour to give as many people as possible, including workers, the opportunity to visit it.

Like a continuous thread the praise bestowed by Fischer on British science and scientists runs through his diaries. In 1825 he was received with great courtesy and kindliness by Michael Faraday in his Royal Institution laboratory. The small size of this well-equipped but overcrowded room impressed on the visitor some comparisons with Paris (Ecole des Mines) and Vienna (Polytechnic Institute-"really imperial"). Faraday, who had himself studied the preparation of new kinds of steel, showed a lively interest in Fischer's "meteor-steel", the extraordinary qualities of which he admired.

The second meeting of the two men took place in the following year when they earnestly discussed "the varieties and nature of metals". Faraday seems to have been very much impressed by the lively mind of the Schaffhausen manufacturer. He said: "I see well you are a practical man and the simple observations of such ones will often do more good to society than all our speculations", a compliment with which his guest was quite satisfied.

At their third meeting in 1845 the conversation turned around the electric telegraph. Fischer made the learned man a present of a crucible for experiments. Faraday had just returned from a holiday in France; his health was poor and for the last time Fischer enjoyed "the warm and cordial reception" given by Faraday on June 19, 1851. The reports of these meetings throw light on the character of both men; they confirm the personal charm for which the great scholar was noted.

Fischer also attended the lectures on chemistry given in the Royal Institution by Professor William Thomas Brande (1788-1866), the secretary of the Institution, whom he regarded as an insignificant scientist. He was impressed by the applications to medicine and surgery which the lecturer often illustrated. The Swiss expert regretted that in his native town nothing could yet be done "for this so valuable science". The chemical industry in Basle was, of course, developing rapidly (Ciba, Ltd., 1959). He remained in touch with Brande until 1851, when the latter was a Director of the die stamp office in the Royal Mint. The nature of metals formed the centre of conversation between these two men.

\section{Industry and Technology}

In 1825 Fischer had his first contact with the unflagging advance of British science in industry. At Apothecaries Hall he was shown coal-gas and oilgas lighting, demonstrated by Faraday. During his first visit in 1814 he had seen the steam-engine of
James Watt (1736-1819) and Matthew Boulton (1728-1809). The Swiss guest was highly impressed by its use and did not fail to correlate this invention with the rising prosperity of industry since the 18th century.

Fischer was overwhelmed by the appearance of the steam-engine in the factory. He reports: "A description would be useless; the imagination could never follow it . . . the former monstrous compilation of tubes and cylinders at the steam-engines has now become an elegant iron building with columns of Doric and Corinthian orders". The beauty of technical formation here found one of its early admirers.

On his further visits to English factories, Fischer thought that Watt's invention could be extended almost indefinitely. He named one factory "the iron house", because all floors and stairways consisted "of founded iron, finely chequered like carpets. Here were the working steam-engines with six to fifty horsepower, performing evenly and uniformly the labour imposed on them by their inventor". He gives a complete catalogue of the manufacturing processes. "All this work was undertaken in the bright light of gas-lamps, which were supplied by huge tanks situated in a separate building; the lighting-gas was produced within the factory by the distillation of coal." The visitor was much interested in the invention of lighting-gas. His summary of a treatise by the engineer William Murdock (1754-1839) reads: "this paper was submitted to the Royal Society by the inventor of gaslighting (1814). Actually, it was an accumulation of technical miracles which should fill a progressive specialist with enthusiasm".

The engines in the workshops of Wedgwood's porcelain factory and the looms of a textile factory in Manchester were operated by steam. A dyeworks for woollen fabrics in Leeds was equipped with steam heating. If we add the further propelling force of an Archimedean screw for the regulation of the incoming air in the furnaces of a foundry, we get an approximate idea of the variety of new techniques offered to the wondering eyes of the visitor.

But even a manufacturer believing in progress was frightened by all these improvements. Fischer went to Leeds in order to study the use of the steamengine for locomotive purposes. He reports: "Vans for the transportation of coal were drawn on an iron railway for a distance of almost three English miles". Here, on the evening of September 3,1814 , the visitor met a scene which he describes in detail:

"The van on which is the steam-engine, and which in size and form equals a wine-van with a single barrel, has also four low iron wheels like the vans attached at the end; it has a fifth toothed-wheel in front, which is in the 
middle of the left two wheels before and behind. This toothed-wheel grasps in the cogs and is moved by the two smaller wheels in front."

Then follows the description of the "piston-handles in two cylinders of 12 inches size moved by the steamengine. In the boiler itself is also the kiln in order to produce the largest quantity of steam by a small fire".

The name "locomotive" is not used-it was introduced by Stephenson only in 1825-but there is no doubt that Fischer describes here one of the first examples of this type of engine. The construction was by M. Murray (1756-1826), an English engineer. This "van of triumph of the human mind", as it is called by Fischer, deserves to be quoted beside the "Invicta" (1804) of Trevithick and the "Puffing Billy" (1813) of William Hedley.

At his same visit Fischer had travelled some distance to meet the "vehicle". The man "who guided it" called him

"to jump up on the van which was supplied with two benches on each side, and for my pleasure he lifted the machine to an easy trot. He increased the speed of the pistons to eighty strokes a minute by a stronger production of steam. But I was glad when he eased up again, because of the apparent danger of an explosion. For the steam whistled as if half a dozen asthmatic horses driven out of breath were being relayed."

But the story had a happy end, and Fischer entered the town of Leeds in this unique manner. He was amazed at the immense force this engine developed for it was able to move 23 "completely iron vans" with 60 hundredweight of coal each "on a plane sometimes climbing ... by the same speed". Our man of Schaffhausen who had been so greatly rewarded by his trip to Leeds was fully justified in writing the following words: ". . . for such a purpose the elements have not previously been harnessed with such concentrated power in such a small room". Fischer was very sorry that he did not meet personally "the famous Murray" as he called him in 1825.

But it was not only the locomotive engine which would very soon revolutionize public life in England. Steam navigation was already used in great measure on the river Thames. As innovations there were the production of artificial ice (1826), the use of coal-tar dyes to increase the durability of wood, an original apparatus for diving (1846), and photography. The photographer Croucher in 1825 made a good portrait of Fischer "in coloured Daguerrotype", an invention of more than cultural significance in our days.

In the introduction to his diary of 1845 Fischer enumerates the remarkable developments in British industry since his travels in the 1820's when only the steam-engine meant something new in contrast with the continent. This one indication shows that within two decades in the British Isles modern techniques in industry had been created.

\section{The Social Situation}

How did the workers live in this world of "Pantechnotheka", as one of the modern buildings of the new town of Birmingham was called? Compared with his detailed descriptions of machines and equipment, Fischer's references to social conditions are scanty. Nevertheless, he did not overlook the negative side of this great technical progress. In the last years of his life he saw the social problems in a rather different light.

Switzerland could not keep up with the imposing number of manual workers employed in England. In 1814 Fischer found that the large ironworks in Broseley (near Birmingham) over which its founder John Wilkinson (1728-1808) "ruled like a king", employed over 5,000 male workers alone. It impressed Fischer that Wilkinson's successor Ferryday, had once been "a common coal-heaver". The spinning mill of Gott in Leeds counted 1,000 men and during the wars even twice as many.

After his visit to a textile mill in Manchester in 1814 Fischer fully understood the revolt of the weavers near Nottingham and in some other places reported in the newspapers some years previously. At that time the workers had attempted to demolish the machines and the buildings containing them. Fischer was not surprised at this after he had seen the machine looms. He describes the conditions in a factory in relation to the employees:

"50 looms moved by one single steam-engine stood in a room of middle size. Each loom measured 4 feet in length, breadth and height. 15 persons and a supervisor looked after them."

Again near Manchester, Phillips, the owner of a large ironworks, complained to Fischer in 1825 of "the rebellious workers". Fischer drew a parallel between the circumstances in Schaffhausen and those in Manchester and added that "our people accustomed to a much simpler life would be glad to receive the high wages paid in England (24-26 shillings a week) even allowing for the higher cost of living".

Fischer saw child labour at Gott's factory. He mentions it only in connexion with the fact that, because of the quality and the precision of the looms, only a measure of supervision was needed. He says that one little child was more than enough for the care of two machines opposite each other and each containing 50 spindles. Any criticism against child labour is lacking.

Fischer mentions in passing that, in hackling the flax on the loft, the windows were kept open during 
summer and winter because of "the horrible dust", but there is no allusion to the possibility of an industrial disease caused by the dust.

Fischer's report of his visit to the 1851 Exhibition concludes on a warning note. He discusses the "workers' associations" from which he considered there was heavy but partially concealed pressure to improve conditions. He saw the great contrast between the working class of society-and he visited many workers "in their low dark dwellings"-and the luxury enjoyed by relatively small parts of the nation. Fischer foresees a grave future on account of overproduction; the lot of the poorest inhabitants, namely, the factory-workers, condemned to inactivity, would become a burden for the country. It is interesting to note at the present time that, according to Fischer, even the introduction of Free Trade would not be able to put a stop to this development.

Fischer met Robert Owen (1771-1858) in 1825 and he appears to have appreciated Owen's qualities as a reformer. A statement made by a clerk in Gott's textile firm shows clearly that the philanthropic ideas of Owen had been accepted willingly by certain circles in the industry. He gave Fischer, with whom he had a long discussion, a pamphlet by Owen which "should contain all that is needed to make men happy".

How great was the contrast between reality and the ideal postulates of Owen! In Sheffield, work lasted until late on Saturday nights, and in England, as Fischer writes in 1846, there were none of the rather easy rest pauses "met with in our country" where a man could find time "to load and to light a pipe". Towns like Manchester and Birmingham are "enveloped by a standing cloud of smoke". By this statement Fischer did not mean to diminish the merits of "the poor barber Arkwright", the inventor of the steam jenny, who had contributed so much to the greatness of Manchester. But he remembered the poor dwellings of the workers with their rare windows and he compared them very unfavourably with the "friendly farmhouses" of Switzerland which he knew so well.

In the middle of the hurry and bustle of the great Exhibition, the man of Schaffhausen wrote a meditative contemplation to which, in a large town, one can be urged even today. He calls his notes "a short and certainly not exaggerated sketch of London life in general", but is anxious, at the same time, to plan the reversal of the features he disliked in the urban environment. He thinks that English people are "much more devoted to home life than are their neighbours on the other side of the Channel".

Finally, Fischer draws the picture of the large town:

"Grey and black-brown the rows of houses without end, noise and din of innumerable vehicles without cease, laconic conversation or complete silence in the dining-rooms of the restaurants ... where every arriving person first looks for a free table and as quickly as possible barricades himself behind an immense newspaper ... The large towns, with few exceptions, are for the people who must remain there for their whole distressing lives, indeed they resemble gaols ... Never or extremely seldom a bright sky like ours laughs to the man of London; he does not see the beautiful meadows, the flowing brooks, the green woods, nor ever imagine the lovely silver wraith of our Alps."

I hope that the strong voice of Fischer's philosophy, out of the dynamic 19th century, has spoken to us with lasting effect.

\section{REFERENCES}

Ciba, Ltd. (1959). The Story of Chemical Industry in Basle. Urs Graf, Olten and Lausanne.

Fischer, Johann Conrad (1951). Tagebücher (1794-1851). Fischer, Schaffhausen, Switzerland.

Morazé. Charles (1959). Das Gesicht des 19. Jahrhunderts. Diederichs, Düsseldorf, Köln.

Ritchie, R. (1846). Railways; Their Rise, Progress and Construction: With Remarks on Railway Accidents, and Proposals for their Prevention. Longman, Brown, Green and Longmans, London. 